\title{
EFEKTIFIKASI PERADILAN TATA USAHA NEGARA DALAM MENYELESAIKAN SENGKETA TATA USAHA NEGARA
}

\author{
Oleh: \\ Tetti Samosir \\ Fakultas Hukum Universitas Pancasila, Jakarta \\ Email: tettisamosir2015@gmail.com
}

\begin{abstract}
ABSTRAK
Menurut Pasal 1 ayat (3) Undang-Undang Dasar 1945 Indonesia adalah negara hukum. Salah satu konsekuensi negara hukum adalah adanya peradilan yang bebas. Untuk itu, telah diletakkan dasar hukum peradilan di Indonesia sebagaimana termaktub di dalam Pasal 24 UUD 1945. Di dalam Pasal 24 ayat (1) UUD 1945 disebutkan, Kekuasaan Kehakiman merupakan kekuasaan yang merdeka untuk menyelenggarakan peradilan guna menegakkan hukum dan keadilan. Berkaitan dengan kekuasaan kehakiman tersebut diatur dalam Undang Undang Nomor 14 Tahun 1970 tentang Ketentuan-Ketentuan Pokok Kekuasaan Kehakiman yang diubah dengan Undang-Undang Nomor 4 Tahun 2004 tentang Kekuasaan Kehakiman dan kemudian diubah dan disempurnakan dengan Undang-Undang Nomor 48 Tahun 2009 tentang Kekuasaan Kehakiman.

Secara khusus untuk badan peradilan yang ada di lingkungan Peradilan Tata Usaha Negara telah diatur dalam Undang-Undang Nomor 5 Tahun 1986 tentang Peradilan Tata Usaha Negara diubah dengan Undang-Undang Nomor 9 Tahun 2004 tentang perubahan atas Undang-Undang Nomor 5 Tahun 1986 tentang Peradilan Tata Usaha Negara yang kemudian diubah dengan Undang-Undang Nomor 51 Tahun 2009 tentang Perubahan Kedua atas Undang-Undang Nomor 5 Tahun 1986 tentang Peradilan Tata Usaha Negara.

Salah satu tujuan dibentuknya Peradilan Tata Usaha Negara adalah untuk mewujudkan tata kehidupan negara dan bangsa yang sejahtera, aman, tenteram serta tertib yang menjamin kedudukan warga masyarakat dalam hukum dan menjamin terpeliharanya hubungan yang serasi, seimbang, serta selaras antara aparatur di bidang tata usaha negara dengan para warga masyarakat. Sehingga masyarakat sangat berharap undang-undang ini mampu menyelesaikan segala persoalan atau sengketa yang timbul dalam bidang tata usaha negara antara orang atau badan hukum perdata (masyarakat) dengan badan atau pejabat tata usaha negara (pemerintah). Orang atau badan hukum perdata yang mengajukan gugatan ke Pengadilan Tata Usaha Negara, atas Keputusan Tata Usaha Negara yang dikeluarkan oleh Badan atau Pejabat Tata Usaha Negara. Karena Keputusan Tata Usaha Negara tersebut,telah mengakibatkan kerugian terhadap orang atau badan hukum perdata yang selanjutnya disebut sebagai Penggugat. Gugatan Penggugat atas Keputusan Tata Usaha Negara yang dikeluarkan oleh Badan atau Pejabat Tata Usaha Negara tersebut, dikabulkan dan dimenangkan oleh penggugat, dan telah mempunyai kekuatan hukum tetap (inkracht van gewijsde). Namun, dalam pelaksanaannya, Putusan Pengadilan Tata Usaha Negara yang dimenangkan Penggugat, tidak ditaati atau dilaksanakan oleh Badan atau Pejabat Tata Usaha Negara (Tergugat), terhadap Badan atau Pejabat Tata Usaha Negara (Tergugat)
\end{abstract}


yang tidak mau melaksanakan dan mengabaikan putusan pengadilan tersebut ternyata tidak ada sanksi hukum yang tegas.

Kata kunci: Keputusan Tata Usaha Negara, Sengketa Tata Usaha Negara, Keadilan, kepastian hukum, dan kekuatan eksekutorial Putusan Pengadilan Tata Usaha Negara.

\begin{abstract}
According to Article 1 (3) of the Constitution1945, Indonesia is a state of law. The either consequences of a state of law is the independent judiciary. For that, it has laid the legal basis for justice in Indonesia as set forth in Article 24 of the Constitution 1945. In the Article 24 paragraph (1) of the Constitution mentioned that the Judicial Power is an independent power to organize judicial administration to uphold the law and justice. Relating to the judicial power is regulated in Law No. 14 of 1970 concerning basic stipulations of Judicial Power, as amanded by Law No. 4 of 2004 concerning Judicial Power and then modified and refined by Law Number 48 Year 2009 concerning Judicial Power.

Specifically for the judiciary in the environment of the Administrative Courts has been regulated in Law Number 5 of 1986 concerning the Administrative Courts amended by Law Number 9 of 2004 concerning amendments to the Law Number 5 of 1986 concerning the Administrative Courts which then amanded by Law Number 51 Year 2009 concerning the Second Amendment to Law Number 5 of 1986 concerning the Administrative Court.

One of purpose of establishing the Administrative Court is to actualize order of life of the state and nation that is prosperous, secure, peaceful and orderly, which ensures the position of citizens in the law and ensure the maintenance of a harmonious relationship, balance, and harmony between personnel in the field of state administration with the citizens. So that the community is hoping this legislation capable of resolving all matters or disputes arising in the field of the state administrative between person or civil legal entity (society) with the agency or state administrative official (government).

Person or civil legal entity may submit law suit to the Administrative Court, on an administrative decision issued by the Agency or the Administrative Officer. because the administrative state decision has resulted loss at person or civil legal entity, hereafter referred to as plaintiff. The lawsuit of plaintiff at the administrative state decision issued by agency or administrative official that, granted and won by the plaintiff, and has had permanent legal force (inkracht van gewijsde).

However, in practice, the verdict of administrative court which be won by plaintiff, is not adhered or implemented by agency or state administrative official (defendant). To Agency or State Administration Official (Defendant) that do not want implement and ignore that court's ruling was not there are strict legal sanctions.
\end{abstract}

Keywords : An administrative state decision, the Administrative state Dispute, justice, rule of law, and the strength of the decision executorial Administrative Court. 


\section{PENDAHULUAN}

Sebagai negara yang demokratis, Indonesia memiliki sistem ketatanegaraan dengan memiliki lembaga eksekutif, legislatif dan yudikatif. Dari ketiga lembaga tersebut eksekutif memiliki porsi peran dan wewenang yang paling besar apabila dibandingkan dengan lembaga lainnya, oleh karenanya, perlu ada kontrol terhadap pemerintah untuk adanya check and balances. Untuk mengontrol kekuasaan eksekutif tersebut diperlukan lembaga yudikatif atau kehakiman. ${ }^{1}$ Berkaitan dengan kekuasaan kehakiman setelah diadakan perubahan/amandemen terhadap Undang-Undang Dasar 1945, dalam Pasal 24 ayat (1) dan ayat (2) Perubahan Ketiga UUD 1945 menyebutkan, bahwa :

(1) Kekuasaan kehakiman merupakan kekuasaan yang merdeka untuk menyelenggarakan peradilan guna menegakkan hukum dan keadilan;

(2) Kekuasaan kehakiman dilakukan oleh sebuah Mahkamah Agung dan badan peradilan yang berbeda di bawahnya dalam lingkungan peradilan umum, lingkungan peradilan agama, lingkungan peradilan militer, lingkungan peradilan tata usaha negara, dan oleh sebuah Mahkamah Konstitusi.

Berdasarkan Pasal 24 UUD 1945 tersebut, dapat diketahui bahwa di Indonesia terdapat 4 (empat) lingkungan peradilan, yaitu :

1. Lingkungan Peradilan Umum

2. Lingkungan Peradilan Agama

3. Lingkungan Peradilan Militer

4. Lingkungan Peradilan Tata Usaha Negara

Sebagai ketentuan pelaksana yang mengatur tentang lingkungan peradilan di Indonesia, selanjutnya diatur dalam Undang-Undang Nomor 14 Tahun 1970 tentang Ketentuan-ketentuan Pokok Kekuasaan Kehakiman yang diubah dengan Undang-Undang Nomor 4 Tahun 2004 tentang Kekuasaan Kehakiman dan kemudian diubah dan disempurnakan dengan Undang-Undang Nomor 48 Tahun

${ }^{1}$ http://www.google.com/search?q=kekuatan+eksekutorial+putusan-PTUN\&ie=utf, diakses pada hari selasa, 2 November 2015, Pukul 19.26 Wib. 
2009 tentang Kekuasaan Kehakiman, Pada Pasal 18 UU No. 48 Tahun 2009 disebutkan, bahwa :

"Kekuasaan kehakiman dilakukan oleh sebuah Mahkamah Agung dan badan peradilan yang berada di bawahnya dalam lingkungan peradilan umum, lingkungan peradilan agama, lingkungan peradilan militer, lingkungan peradilan tata usaha negara, dan oleh sebuah Mahkamah Konstitusi”.

Atas dasar ketentuan tersebut, maka secara khusus untuk badan peradilan yang ada di lingkungan Peradilan Tata Usaha Negara telah diatur dalam UndangUndang Nomor 5 Tahun 1986 tentang Peradilan Tata Usaha Negara diubah dengan Undang-Undang Nomor 9 Tahun 2004 tentang perubahan atas UndangUndang Nomor 5 Tahun 1986 tentang Peradilan Tata Usaha Negara yang kemudian diubah dengan Undang-Undang Nomor 51 Tahun 2009 tentang Perubahan Kedua atas Undang-Undang Nomor 5 Tahun 1986 tentang Peradilan Tata Usaha Negara.

Ketika Undang-Undang Nomor 5 Tahun 1986 tentang Peradilan Tata Usaha Negara diundangkan pada tanggal 29 Desember 1986, dimuat dalam LN Th. 1986 No. 77, TLN No. 3344, masyarakat sangat berharap undang-undang ini mampu menyelesaikan segala persoalan atau sengketa yang timbul dalam bidang tata usaha negara antara orang atau badan hukum perdata (masyarakat) dengan badan atau pejabat tata usaha negara (pemerintah). Dalam konsideran UndangUndang No. 5 Tahun 1986 tersebut, disebutkan "Menimbang” bahwa salah satu tujuan dibentuknya Peradilan Tata Usaha Negara adalah untuk mewujudkan tata kehidupan negara dan bangsa yang sejahtera, aman, tenteram serta tertib yang menjamin kedudukan warga masyarakat dalam hukum dan menjamin terpeliharanya hubungan yang serasi, seimbang, serta selaras antara aparatur di bidang tata usaha negara dengan para warga masyarakat. Dengan demikian lahirnya Peradilan Tata Usaha Negara juga menjadi bukti bahwa Indonesia adalah negara hukum yang menjunjung tinggi nilai-nilai keadilan, kepastian hukum dan Hak Asasi Manusia (HAM). ${ }^{2}$ Akan tetapi, pada kenyataannya banyak yang kecewa, sebab undang-udang ini ternyata tidak mampu memenuhi harapan

\footnotetext{
${ }^{2}$ Ibid.
} 
masyarakat. Walaupun telah dilakukan perubahan dua kali terhadap Undang Undang Nomor 5 Tahun 1986, yaitu denganUndang-Undang Nomor 9 Tahun 2004 tentang perubahan atas Undang-Undang Nomor 5 Tahun 1986 tentang Peradilan Tata Usaha Negara (LN Th. 2004 No. 35, TLN No. 4380) diundangkan pada tanggal 29 Maret 2004 yang kemudian diubah dengan Undang-Undang Nomor 51 Tahun 2009 tentang Perubahan Kedua atas Undang -Undang Nomor 5 Tahun 1986 tentang Peradilan Tata Usaha Negara (LN Th. 2009 No. 160, TLN No. 5079) yang diundangkan pada tanggal 29 Oktober 2009, tetap saja hasilnya tidak memuaskan dan belum memenuhi harapan masyarakat pencari keadilan.

Kekecewaan masyarakat itu terjadi, karena ketika ada masyarakat (orang atau badan hukum perdata) yang mengajukan gugatan ke Pengadilan Tata Usaha Negara, dimana kemudian gugatan yang diajukan tersebut ternyata dikabulkan atau dimenangkan. Namun, dalam kenyataannya Putusan pengadilan yang memenangkan atau mengabulkan gugatan dari masyarakat (Penggugat) tersebut dalam pelaksanaannya hasilnya sangat mengecewakan, karena kemenangan yang diperoleh oleh Penggugat terkadang tidak dapat dinikmati sebagaimana mestinya, sesuai dengan yang diputuskan oleh pengadilan yang telah mempunyai kekuatan hukum tetap (inkracht van gewijsde). Karena itu, banyak yang mempertanyakan tentang efektifikasi Peradilan Tata Usaha Negara ini mampu menyelesaikan sengketa tata usaha negara. Atas dasar itu, patut dipertanyakan apakah Peradilan Tata Usaha Negara ini masih diperlukan? Sebagai seorang praktisi (Advokat) pada tahun 2009, penulis sudah pernah mengirimkan surat ke Mahkamah Agung untuk meminta Pengadilan Tata Usaha Negara tersebut dibubarkan saja. Surat tersebut diajukan karena penulis sangat kecewa, sebab beberapa putusan Pengadilan Tata Usaha Negara yang telah mempunyai kekuatan hukum tetap yang pada saat itu, penulis menangkan tidak dilaksanakan oleh Badan atau Pejabat Tata Usaha Negara (Tergugat). Padahal, berperkara di Pengadilan Tata Usaha Negara tidaklah mudah. Sebab dalam prakteknya, menyelesaikan masalah atau perkara melalui lembaga peradilan memerlukan biaya yang cukup mahal dan memerlukan waktu yang lama. 


\section{Sengketa Tata Usaha Negara}

Menurut Pasal 1 ayat (3) UUD 1945 Indonesia adalah negara hukum. Salah satu konsekuensi negara hukum adalah adanya peradilan yang bebas. Untuk itu, telah diletakkan dasar hukum peradilan di Indonesia sebagaimana termaktub di dalam Pasal 24 UUD 1945. Di dalam Pasal 24 ayat (1) UUD 1945 disebutkan, Kekuasaan Kehakiman merupakan kekuasaan yang merdeka untuk menyelenggarakan peradilan guna menegakkan hukum dan keadilan. Bertalian dengan itu, dalam konsep pembangunan yang diselenggarakan di Indonesia perlu dicari cara-cara, yang disatu pihak dapat menjamin wewenang bertindak dan mengatur dari pemerintah dan dilain pihak dapat menjamin bahwa wewenang bertindak dan mengatur tersebut tidak melanggar hak-hak asasi warga negaranya. Hal itu sesuai dengan pendapat Sri Soemantri ${ }^{3}$ yang menyebutkan bahwa di dalam negara hukum terdapat 4 (empat) unsur penting, yakni :

1. Bahwa pemerintah dalam melaksanakan tugas dan kewajibannya harus berdasar atas hukum atau peraturan perundang-undangan;

2. Adanya jaminan terhadap hak-hak asasi manusia (warga negara);

3. Adanya pembagian kekuasaan dalam negara;

4. Adanya pengawasan dari badan-badan peradilan (rechterlijke controle).

Berdasarkan uraian di atas, tampak bahwa negara hukum tersebut mempunyai tujuan untuk melindungi hak asasi manusia, yang untuk itu harus ada sarana hukum, diadakan pemisahan atau pembagian serta pembatasan kekuasaan di dalam negara, serta adanya peadilan yang bebas.

Untuk merealisasikan maksud tersebut di atas, selanjutnya hal itu dijelmakan kedalam berbagai peraturan perundang-undangan. Khusus mengenai Peradilan Tata Usaha Negara telah diterbitkan UU. No. 5 Tahun 1986 tentang Peradilan Tata Usaha Negara, sebagaimana telah diubah dengan perubahan pertama yakni : dengan UU. No. 9 Tahun 2004 dan perubahan kedua dengan UU. No. 51 Tahun 2009.

${ }^{3}$ Sri Soemantri, Bunga Rampai Hukum Tata Negara Indonesia, (Bandung: Alumni, 1992), hal. 29-30. 
Pasal 4 UU. No. 9 Tahun 2004 menyebutkan, Paradilan Tata Usaha Negara adalah salah satu pelaku kekuasaan kehakiman bagi rakyat pencari keadilan terhadap sengketa Tata Usaha Negara. Selanjutnya dalam Penjelasan disebutkan bahwa yang dimaksud dengan "rakyat pencari keadilan" adalah setiap orang baik warga Negara Indonesia maupun orang asing, dan badan hukum perdata yang mencari keadilan pada Peradilan Tata Usaha Negara.

Pasal 5 ayat (1) UU. No. 5 Tahun 1986 mengatakan, bahwa Kekuasaan Kehakiman di lingkungan Peradilan Tata Usaha Negara dilaksanakan oleh :

a. Pengadilan Tata Usaha Negara,

b. Pengadilan Tinggi Tata Usaha Negara.

Sementara dalam Pasal 5 ayat (2) UU. No. 5 Tahun 1986 menyebutkan, Kekuasaan Kehakiman di lingkungan Peradilan Tata Usaha Negara berpuncak pada Mahkamah Agung sebagai Pengadilan Negara Tertinggi. Dengan demikian, Peradilan Tata Usaha Negara itu dimulai dari :

a. Pengadilan Tata Usaha Negara;

b. Pengadilan Tinggi Tata Usaha Negara; dan

c. Mahkamah Agung.

Menurut Pasal 47 UU. No. 5 Tahun 1986, bahwa pengadilan bertugas dan berwenang memeriksa dan memutus dan menyelesaikan sengketa Tata Usaha Negara. Tetapi, di dalam Pasal 48 ayat (1) UU. No. 5 Tahun 1986 disebutkan, bahwa dalam hal suatu Badan atau Pejabat Tata Usaha Negara diberi wewenang oleh atau berdasarkan peraturan perundang-undangan untuk menyelesaikan secara administratif sengketa Tata Usaha Negara tertentu, maka sengketa Tata Usaha Negara tersebut harus diselesaikan terlebih dahulu melalui upaya administratif yang tersedia. Pengadilan baru berwenang memeriksa, memutus dan menyelesaikan sengketa Tata Usaha Negara tertentu sebagaimana dimaksud dalam ayat (1) jika seluruh upaya administratif yang bersangkutan telah ditempuh sebagaimana diatur dalam Pasal 48 ayat (2) UU. No. 5 Tahun 1986. Artinya, tidak seluruh sengketa tata usaha negara dapat langsung diselesaikan melalui Peradilan Tata Usaha Negara, tetapi ada beberapa sengketa yang harus diselesaikan terlebih dahulu melalui upaya administratif. Dalam Penjelasan disebutkan bahwa yang 
dimaksud dengan upaya administratif adalah suatu prosedur yang dapat ditempuh oleh seorang atau badan hukum perdata apabila ia tidak puas terhadap suatu Keputusan Tata Usaha Negara. Upaya administratif tersebut dilaksanakan berdasarkan (2) dua bentuk, yaitu. Pertama, Keberatan: Penyelesaian oleh instansi yang sama. Dengan pengajuan surat keberatan (bezwaarschrift) yang ditujukan kepada Badan atau Pejabat Tata Usaha Negara yang mengeluarkan keputusan Tata Usaha Negara. Kedua, Banding Administratif : Penyelesaian oleh instansi atasan atau instansi lain dari yang mengeluarkan Keputusan Tata Usaha Negara. Dengan prosedur pengajuan melalui surat banding administratif (administratief beroep) yang ditujukan kepada atasan pejabat atau instansi lain dari yang mengeluarkan keputusan Tata Usaha Negara atau instansi lain yang berwenang untuk memeriksa ulang keputusan Tata Usaha Negara yang disengketakan.

Apabila upaya tersebut telah ditempuh oleh pihak-pihak yang bersengketa akan tetapi tidak ada penyelesaiannya, maka dalam ketentuan Pasal 53 ayat (1) UU No. 9 Tahun 2004 menyebutkan, bahwa : "orang atau badan hukum perdata yang merasa kepentingannya dirugikan oleh suatu keputusan tata usaha negara dapat mengajukan gugatan tertulis kepada pengadilan yang berwenang yang berisi tuntutan agar keputusan Tata Usaha Negara yang disengketakan itu dinyatakan batal atau tidak sah dengan atau tanpa disertai tuntutan ganti rugi dan/atau direhabilitasi”. Selanjutnya dalam ayat (2) disebutkan alasan-alasan yang dapat digunakan dalam gugatan adalah, bahwa : a. Keputusan Tata Usaha Negara yang digugat itu bertentangan dengan peraturan perundang-undangan yang berlaku; $b$. Keputusan Tata Usaha Negara yang digugat itu bertentangan dengan asas-asas umum pemerintahan yang baik.

Gugatan yang dimaksud mengacu kepada ketentuan dalam Pasal 1 angka 11 UU No. 51 Tahun 2009, merupakan permohonan yang berisi tuntutan terhadap badan atau pejabat tata usaha Negara karena merasa kepentingannya dirugikan harus diajukan secara tertulis dan diajukan ke pengadilan untuk mendapatkan putusan sebagai koreksi terhadap penerapan hukumnya. ${ }^{4}$

${ }^{4}$ Eko Sugitario dan Tjondro Tityamulia, Hukum Acara Peradilan Tata Usaha Negara, (Surabaya: Brilian Internasional, 2012), hal. 28. 
Di samping hal seperti disebutkan di atas, dalam Pasal 49 UU. No. 5 Tahun 1986 disebutkan, pengadilan tidak berwenang memeriksa, memutus dan menyelesaikan sengketa Tata Usaha Negara tertentu dalam hal keputusan yang disengketakan itu dikeluarkan :

a. Dalam waktu perang, keadan bahaya, keadaan bencana alam atau keadaan luar biasa yang membahayakan berdasarkan peraturan perundangundangan yang berlaku;

b. Dalam keadaan mendesak untuk kepentingan umum berdasarkan peraturan perundang-undangan yang berlaku.

Dalam Pasal 50 UU. No. 5 Tahun 1986 disebutkan Pengadilan Tata Usaha Negara bertugas dan berwenang memeriksa, memutus dan menyelesaikan sengketa Tata Usaha Negara di tingkat pertama.

Berdasarkan ketentuan di atas, dapat dikemukakan bahwa wewenang Peradilan Tata Usaha Negara ialah mengadili sengketa Tata Usaha Negara antara orang atau badan hukum perdata dengan badan atau pejabat Tata Usaha Negara. Bahwa yang dimaksud dengan sengketa Tata Usaha Negara menurut Pasal 1 angka 10 Undang-Undang No. 51 Tahun 2009 tentang Perubahan Kedua UndangUndang No. 5 Tahun 1986 tentang Peradilan Tata Usaha Negara adalah :

"Sengketa tata usaha negara adalah sengketa yang timbul dalam bidang Tata Usaha Negara antara orang atau Badan Hukum Perdata dengan Badan atau Pejabat tata usaha negara, baik di pusat maupun di daerah, sebagai akibat dikeluarkannya Keputusan tata usaha negara, termasuk sengketa kepegawaian berdasarkan peraturan perundang-undangan yang berlaku”.

Berdasarkan pengertian di atas, dapat disimpulkan bahwa sengketa Tata Usaha Negara merupakan sengketa yang timbul dalam bidang Tata Usaha Negara antara orang atau badan hukum perdata dengan pejabat Tata Usaha Negara sebagai akibat dikeluarkannya keputusan Tata Usaha Negara. Keputusan Tata Usaha Negara sebagaimana diatur dalam Pasal 1 angka 9 UU. No. 51 Tahun 2009. Keputusan Tata Usaha Negara menurut Pasal 1 angka 9 UU. No. 51 Tahun 2009 yaitu suatu penetapan tertulis yang dikeluarkan oleh Badan atau Pejabat Tata Usaha Negara yang berisi tindakan hukum Tata Usaha Negara yang berdasarkan 
peraturan perundang-undangan yang berlaku, yang bersifat konkret, individual dan final yang menimbulkan akibat hukum bagi seseorang atau badan hukum perdata. Konkret,maksudnya adalah mengatur suatu hal yang jelas atau tidak abstrak. Individual, maksudnya jelas ditujukan kepada seseorang tertentu. Final, maksudnya adalah bahwa Surat Keputusan tersebut sudah definitif dan telah dilaksanakan yang menimbulkan suatu akibat hukum. Misalnya, kehilangan pekerjaan atau diberhentikan sebagai Pengawai Negeri Sipil, kehilangan rumah dan lain sebagainya. Dengan demikian, unsur-unsur sengketa tata usaha negara adalah :

a. Subyeknya orang atau badan hukum perdata di satu pihak dan badan atau Pejabat Tata Usaha Negara di lain pihak.

b. Obyek sengketa adalah keputusan yang dikeluarkan oleh badan atau Pejabat Tata Usaha Negara.

Di samping hal seperti diuraikan di atas, haruslah diperhatikan tentang batas waktu mengajukan gugatan. Seseorang atau badan hukum perdata yang berniat untuk mengajukan gugatan terhadap keputusan Tata Usaha Negara yang dirasakan merugikan, dan menurut peraturan dasarnya tidak terdapat kewajiban untuk diselesaikan dengan prosedur upaya administratif, maka gugatan dapat diajukan dalam tenggang waktu 90 (sembilan puluh) hari sejak diterimanya atau setelah diumumkannya keputusan Tata Usaha Negara tersebut, sebagaimana dimaksud dalam ketentuan Pasal 55 Undang-Undang Nomor 9 Tahun 2004 tentang Perubahan Atas Undang-Undang Nomor 5 Tahun 1986 tentang Peradilan Tata Usaha Negara. Apabila batas waktu yang ditentukan ini lewat, maka gugur hak untuk mengajukan gugatan.

\section{Efektifikasi Peradilan Tata Usaha Negara}

Sebagaimana dikemukakan di atas, bahwa sebagai konsekuensi negara hukum, Indonesia membangun lembaga peradilan berdasarkan Pasal 24 UUD 1945. Lembaga peradilan yang berada di bawah Mahkamah Agung adalah salah satu lembaga negara yang mempunyai fungsi untuk menegakkan hukum. Lembaga ini adalah sebagai benteng terakhir dalam menyelesaikan persoalan hukum termasuk sengketa tata usaha negara. Sjachran Basah mengatakan, bahwa : 
Peradilan adalah segala sesuatu yang bertalian dengan tugas memutus perkara dengan menerapkan hukum, menemukan hukum in concreto dalam mempertahankan dan menjamin ditaatinya hukum materiil dengan menggunakan cara prosedural yang ditetapkan oleh hukum formal. ${ }^{5}$

Disamping fungsi seperti disebutkan di atas, peradilan juga berfungsi untuk melengkapi ketentuan-ketentuan hukum positif melalui pembentukkan dan penemuan hukum. Pendapat ini sesuai dengan apa yang dikemukakan oleh Mochtar Kusumaatmadja dan Arief Sidharta yang mengatakan, bahwa lembaga peradilan termasuk Mahkamah Agung mempunyai kedudukan penting dalam sistem hukum Indonesia, karena putusan yang dilahirkan oleh lembaga peradilan pada hakikatnya akan melengkapi ketentuan-ketentuan hukum tertulis melalui pembentukan hukum (rechtsvorming) dan penemuan hukum (rechtsvinding). Dengan kata lain, hakim melalui yurisprudensi mempunyai fungsi membuat hukum baru (creation of new law). ${ }^{6}$

Menurut Rochmat Soemitro ${ }^{7}$ ada 4 unsur penting yang harus dipenuhi oleh peradilan, yakni :

a. Adanya aturan hukum yang abstrak yang mengikat umum yang dapat diterapkan pada suatu persoalan;

b. Adanya suatu perselisihan hukum yang konkrit;

c. Ada sekurang-kurannya dua pihak;

d. Adanya suatu aparatur peradilan yang berwenang memutus peradilan.

Terhadap pendapat Rochmat Soemitro ini, Sjachran Basah $^{8}$ menambahkan unsur hukum formal dalam rangka penerapan hukum (rechtstoepassing) dan menemukan hukum (rechtsvinding) "in concreto" untuk menjamin ditaatinya hukum materiil. Berdasarkan kedua pendapat di atas, unsur peradilan itu menjadi :

${ }^{5}$ Sjachran Basah,Eksistensi dan Tolok Ukur Badan Peradilan Administrasi di Indonesia, (Bandung: Alumni, 1997), hal. 23.

${ }^{6}$ Mochtar Kusumaatmadja dan Arief Sidharta, Pengantar Ilmu Hukum : Suatu Pengantar Ruang Lingkup Berlakunya Ilmu Hukum, Buku I, (Bandung: Alumni, 1999), hal. 99.

Rochmat Soemitro, Masalah Peradilan Administrasi dalam Hukum Pajak di Indonesia, (Bandung: Eresco, 1976), hal. 7-8.

${ }^{8}$ Sjachran Basah, Op. cit, hal. 29. 
a. Adanya aturan hukum yang abstrak yang mengikat umum yang dapat diterapkan pada suatu persoalan;

b. Adanya suatu perselisihan hukum yang konkrit;

c. Ada sekurang-kurangnya dua pihak;

d. Adanya suatu aparatur peradilan yang berwenang memutus peradilan;

e. Adanya hukum formal untuk menjamin ditaatinya hukum materiil.

Pasal 4 ayat (2) UU. No. 48 Tahun 2009 tentang Kekuasaan Kehakiman menyebutkan, bahwa: pengadilan membantu pencari keadilan dan berusaha mengatasi segala hambatan dan rintangan untuk dapat tercapainya peradilan yang sederhana, cepat dan biaya ringan. Ketentuan ini dimaksudkan untuk memenuhi harapan para pencari keadilan. Dalam Penjelasan Pasal 4 ayat (2) tersebut, dikemukakan bahwa yang dimaksud dengan "sederhana" adalah pemeriksaan dan penyelesaian perkara dilakukan dengan acara yang efisien dan efektif. Biaya ringan adalah biaya perkara yang dapat dijangkau oleh masyarakat. Namun demikian, asas sederhana, cepat dan biaya ringan dalam pemeriksaan dan penyelesaian perkara di pengadilan tidak mengesampingkan ketelitian dan kecermatan dalam mencari kebenaran dan keadilan.

Apa yang dicantumkan di dalam Pasal 4 ayat (2) di atas, pada tataran implementatif belum dapat diwujudkan. Bukan rahasia umum lagi bahwa dalam prakteknya, penyelesaian perkara cenderung memakan waktu yang relatif lama (time consuming in settling cases), prosedur yang berbelit-belit dengan biaya yang mahal. Tunggakan berkas perkara di Mahkamah Agung pernah mencapai angka 20 ribu lebih. Besarnya jumlah tunggakan berkas perkara ini telah menjadi salah satu masalah utama (crucial point $)^{9}$ di samping beberapa persoalan lainnya di tubuh lembaga yang dijuluki sebagai gerbang atau benteng terakhir keadilan ini. Atas dasar itulah Majelis Permusyawaratan Rakyat pernah merekomendasikan agar Mahkamah Agung menyelesaikan tunggakan perkara dengan meningkatkan jumlah dan kualitas putusan ${ }^{10}$.

\footnotetext{
${ }^{9}$ Hendry P. Panggabean, Fungsi Mahkamah Agung Dalam Praktek Sehari-hari, Edisi Revisi, (Jakarta: Pustaka Sinar Harapan, 2002), hal. 165.

${ }^{10}$ Indonesia. Ketetapan MPR No. VIII/MPR/2000 (LN Tahun 2000 No. ) Jo. Ketetapan MPR No. X/MPR/2001 (LN. Tahun 2001 No. ) tentang Rekomendasi MPR kepada Lembaga-lembaga Tinggi Negara.
} 
Sungguh ironis, lembaga yang berfungsi menyelesaikan persoalan hukum masyarakat, justru menimbulkan persoalan hukum yang jauh lebih pelik. Hal ini tentu sangat merugikan masyarakat pencari keadilan, baik moril maupun materiil. Dengan berlarut-larutnya penyelesaian perkara di lembaga peradilan ini, khususnya di Mahkamah Agung, akan menyebabkan terlambatnya masyarakat mendapatkan keadilan, dan hal ini dianggap juga sebagai ketidakadilan (Justice delayed is justice denied $)^{11}$. Kejadian seperti itu sering terjadi dalam penyelesaian sengketa Tata Usaha Negara. Dalam perkara Tata Usaha Negara, sering terjadi perkaranya baru diputus setelah bertahun-tahun. Padahal, kondisi dilapangan sudah sangat berbeda dengan saat perkara diajukan. Misalnya, para pihak ada yang sudah meninggal, terjadi pergantian jabatan, memasuki masa pensiun, dalam sengketa pemilihan kepala daerah masa jabatannya sudah habis, dan sebagainya. Akibatnya, para pihak yang berperkara menjadi kecewa, sebab kemenangan yang didapat menjadi tidak berarti. Hal tersebut merupakan kenyataan dalam penyelesaian perkara pada peradilan Tata Usaha Negara, sehingga, patut dipertanyakan sejauh mana peradilan Tata Usaha Negara dapat menyelesaikan sengketa Tata Usaha Negara?

Persoalan lain yang sering terjadi adalah bahwa Putusan Pengadilan Tata Usaha Negara itu tidak memiliki nilai eksekutorial yang pasti. Karena salah satu yang menyebabkan lemahnya pelaksanaan putusan PTUN adalah tidak terdapatnya lembaga eksekutorial dan kekuatan memaksa dalam pelaksanaan putusan PTUN, sehingga pelaksanaan putusan PTUN tergantung dari kesadaran dan inisiatif dari Pejabat TUN. ${ }^{12}$

Sehingga, ketika perkara dimenangkan oleh Penggugat, seringkali terjadi putusan yang telah mempunyai kekuatan hukum tetap tidak mau dilaksanakan atau diabaikan oleh Badan atau Pejabat Tata Usaha Negara yang menjadi Tergugat dalam perkara tersebut. Hal itu terjadi, karena tidak ada sanksi hukum yang tegas terhadap Badan atau Pejabat Tata Usaha Negara yang tidak mau melaksanakan putusan tersebut. Akibatnya, Penggugat merasa kecewa terhadap

\footnotetext{
${ }^{11}$ Paulus Effendie Lotulung, Perspektif Fungsi Mahkamah Agung ke Depan, (Ulasan Bedah Buku tanggal 23 Januari 2001).

${ }^{12}$ http://www.google.com/search?q=kekuatan+eksekutorial+putusan-PTUN\&ie=utf, diakses pada hari selasa, 2 November 2015, Pukul 19.26 wib.
} 
penegakan hukum di Indonesia, dimana Penggugat hanya menang di atas kertas dan pada kenyataannya putusan tersebut tidak mempunyai arti dan makna, karena tidak dilaksanakan oleh Badan atau Pejabat Tata Usaha Negara (Tergugat). Badan atau Pejabat Tata Usaha Negara tersebut pada kenyataannya, tidak taat terhadap apa yang sudah diperintahkan oleh hukum. Sehingga, patut dipertanyakan arti dan nilai putusan tersebut. Untuk memperoleh putusan yang telah mempunyai kekuatan hukum tetap, tentunya tidaklah mudah. Sebab, putusan tersebut diperoleh setelah melalui proses yang panjang dan memakan biaya yang cukup mahal. Ketika suatu putusan tidak mempunyai arti dan makna tentu hal tersebut sangat mengecewakan Penggugat, dan Penggugat sebagai pencari keadilan mendapat ketidakadilan dan dirugikan lagi atas prilaku Badan atau Pejabat Tata Usaha Negara yang tidak mentaati hukum.

Eko Sugitario dan Tjondro Tirtamulia ${ }^{13}$, mengemukakan, bahwa jika Pejabat yang bersangkutan tetap tidak melaksanakan putusan pengadilan, sejak tidak terpenuhinya ketentuan 90 (sembilan puluh) hari, maka diumumkan pada media massa cetak setempat oleh panitera tentang perintah pengadilan, agar tergugat melaksanakan putusan pengadilan tersebut. Di samping itu, Ketua Pengadilan harus mengajukan hal ini kepada Presiden sebagai pemegang kekuasaan pemerintah tertinggi atau pemimpin tertinggi pemerintahan (dalam rangka pembinaan terhadap aparatur pemerintah yang tidak menjalankan fungsi pemerintahan dengan baik) untuk memerintahkan pejabat tersebut melaksanakan putusan pengadilan, dan kepada lembaga perwakilan rakyat untuk menjalankan fungsi pengawasan.

Dalam hal tergugat ditetapkan harus melaksanakan kewajibannya sebagaimana dimaksud dalam Pasal 97 ayat (9) huruf b (berkaitan dengan pencabutan keputusan Tata Usaha Negara yang bersangkutan dan menerbitkan keputusan Tata Usaha Negara yang baru) dan huruf c (berkaitan dengan penerbitan keputusan Tata Usaha Negara dalam hal gugatan didasarkan pada Pasal 3), dan kemudian setelah 90 (sembilan puluh) hari kerja ternyata kewajiban tersebut tidak dilaksanakan, maka Penggugat dapat mengajukan permohonan kepada Ketua Pengadilan, agar pengadilan memerintahkan Tergugat

\footnotetext{
${ }^{13}$ Eko Sugitario dan Tjondro Tirtamulia, Op. Cit, hlm. 131.
} 
melaksanakan putusan pengadilan tersebut. Di dalam Pasal 116 ayat (4) dan ayat (5) Undang-Undang Nomor 51 Tahun 2009 menyatakan, bahwa :

(4) Dalam hal tergugat tidak bersedia melaksanakan putusan Pengadilan yang telah memperoleh kekuatan hukum tetap, terhadap pejabat yang bersangkutan dikenakan upaya paksa berupa pembayaran sejumlah uang paksa dan/atau sanksi administratif.

(5) Pejabat yang tidak melaksanakan putusan pengadilan sebagaimana dimaksud pada ayat (4) diumumkan pada media massa cetak setempat oleh Panitera sejak tidak terpenuhinya ketentuan sebagaimana dimaksud pada ayat (3).

Berdasarkan apa yang dikemukan di atas, maka dapat disimpulkan bahwa terhadap Badan atau Pejabat Tata Usaha Negara yang tidak melaksanakan dan atau mengabaikan putusan Pengadilan Tata Usaha Negara yang telah mempunyai kekuatan hukum tetap, tidak ada sanksi hukum yang tegas dan hanya lebih menekankan terhadap sanksi moral saja, sehingga Badan atau Pejabat Tata Usaha Negara tersebut menggangap bahwa putusan tersebut boleh dilaksanakan atau tidak dilaksanakan sekalipun tidak akan jadi timbul suatu masalah terhadap instansi atau terhadap Badan atau Pejabat Tata Usaha Negara tersebut.

\section{PENUTUP}

Berdasarkan pembahasan di atas, dapat dikemukakan bahwa efektifikasi Peradilan Tata Usaha Negara dalam menyelesaikan sengketa Tata Usaha Negara masih banyak diperdebatkan. Hal itu terjadi, karena dalam penyelesaian perkaranya masih memerlukan waktu yang lama. Padahal, sering terjadi kondisi dilapangan sudah berbeda dengan saat gugatannya diajukan. Akibatnya, kemenangan itu hanya di atas kertas semata dan tidak dapat dinikmati oleh pihak yang dimenangkan (Penggugat). Di samping itu, masih banyak Badan atau Pejabat Tata Usaha Negara yang mengabaikan dan tidak mau melaksanakan putusan yang telah mempunyai kekuatan hukum yang tetap. Hal itu terjadi karena tidak adanya sanksi hukum yang tegas apabila Badan atau Pejabat Tata Usaha Negara tidak mau melaksanakan putusan yang telah mempunyai kekuatan hukum yang tetap (inkracht van gewijsde). 


\section{DAFTAR PUSTAKA}

Basah, Sjachran. Eksistensi dan Tolok Ukur Badan Peradilan Administrasi di Indonesia. Bandung: Alumni, 1997.

Indonesia. Ketetapan MPR tentang Rekomendasi MPR kepada Lembaga-lembaga Tinggi Negara. Ketetapan MPR No. VIII/MPR/2000 (LN Tahun 2000 No. ) Jo. Ketetapan MPR No. X/MPR/2001 (LN. Tahun 2001 No.)

Kusumaatmadja, Mochtar dan Arief Sidharta. Pengantar Ilmu Hukum: Suatu Pengantar Ruang Lingkup Berlakunya Ilmu Hukum. Buku I, Bandung: Alumni, 1999.

Lotulung, Paulus Effendie. Perspektif Fungsi Mahkamah Agung ke Depan. Ulasan Bedah Buku, tanggal 23 Januari 2001.

Panggabean, Hendry P. Fungsi Mahkamah Agung Dalam Praktek Sehari-hari. Jakarta: Pustaka Sinar Harapan, 2002.

Soemantri, Sri. Bunga Rampai Hukum Tata Negara Indonesia. Bandung: Alumni, 1992.

Soemitro, Rochmat. Masalah Peradilan Administrasi dalam Hukum Pajak di Indonesia. Bandung: Eresco, 1976.

Sugitario, Eko dan Tjondro Tirtamulia. Hukum Acara Peradilan Tata Usaha Negara. Surabaya: Brilian Internasional, 2012.

http://www.google.com/search?q=kekuatan+eksekutorial+putusanPTUN\&ie=utf, diakses pada hari selasa, 2 November 2015, Pukul 19.26 wib. 